\title{
\#2 コータ両面二重塗エの操業経験
}

日本製紙株式会社石卷工場 濱沖賢

\section{Mill Experiences of Double Coating at Nippon Paper Industry-Ishinomaki Mill}

Ken Hamaoki

Ishinomaki Mill, Nippon Paper Industries Co., Ltd.

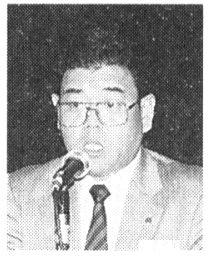

Double Coating is getting popular in production of wood free coated paper grades. This is the world trend. Japanese trend in coated paper production is not free from the world trend. There are several reasons to install new duble coating systems or to replace conventional single coating systems with modern double coating ones. What are the advantages of double coating, paper quality or economy? Our answer is straightforward, "Both". Paper quality and the production cost have to be optimized. Double coating gives us flexibility to optimize the paper quality, the production cost, and runnability, as well. No.2 Coater as Ishinomaki Mill was rebuilt from a single coating blade coater to a double coating blade coater in 1992. In this paper, we describe the fundamental concept for No.2 coater's double coating and the experiences at the mill.

\section{1.はじめに}

日本製紙石巻工場は昭和 13 年東北パルプ石巻工場 として，地元の工業振興を目指し設立された。昭和 47 年に旧十條製紙と合併して以来, 東京から直線で $350 \mathrm{~km}$ の距離, 広い用地, 港湾設備, 用水の好条件 等々の立地の良さから，集中的な生産設備投資を実施 し，国内でも指折りの生産高を誇る基幹工場へと変貌 した。

11 台の抄紙機を擁し， $29 \mathrm{~g} / \mathrm{m}^{2}$ の印刷用紙から 186 $\mathrm{g} / \mathrm{m}^{2}$ の高級コート紙まで，また中質，新聞から微塗 工紙，上質コート紙まで多種多様な種類を生産する印 刷用紙の総合工場である。

年間生産量は約 90 万 $\mathrm{t}$ ，塗工紙がその 6 割を占め ている。
今回の発表テーマに該当する刑 2 コー夕は平成 3 年 7 月にダブルコート設供へと改造された。品質改善, 増 産を主眼とした改造であったが，現在に至るまでの技 術的取組みと成果について以下に報告する。

\section{2. \#2コータの概要紹介}

\section{1 生産品目}

・品種： $\mathrm{A}_{2}$ 厚物のグロスコート紙, マットコー 卜紙, ア一ト紙

- 坪 量: $104.7 \mathrm{~g} / \mathrm{m}^{2} \sim 186 \mathrm{~g} / \mathrm{m}^{2}$

・塗工速度 : $500 \sim 650 \mathrm{~m} / \mathrm{min}$

- 染 工. 巾 : $3,310 \mathrm{~mm}$

・製品 巾: 3,000 3, $250 \mathrm{~mm}$

2.2 設 備 概 要 (図 1)

・ドライブ制御：七クショナルドライブ (ベクトルイ 


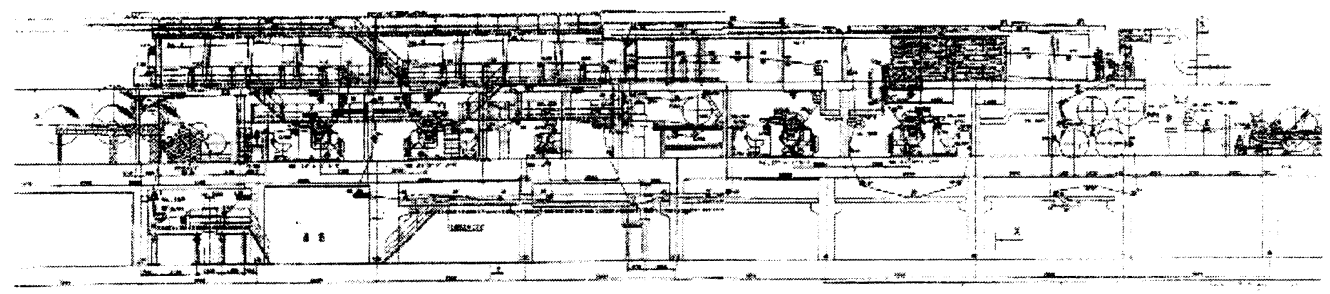

図 1 No.2 コータ

ンバータ) テンションフィードバッ

ク制御

・コータへッド：バリドゥエルタイプ 4 ヘッド (IHI 製)

・乾燥装置：SCAFドライヤ+シリンダドライ $\uparrow$

\section{3. 背景, ダブルコーティングの基礎研究}

\section{1 モットリング対策}

3.1 .1 モットリングの光学的評価方法

クロマトスキャナによるインキ濃度むらの分散分析 法を確立し，目視評価との相関を極めて高いレベルで 実現することができた（図 2)。

\section{1 .2 ダブルコーティングの優位性}

网 2 に六したのは同一の原紙を使用し，同一のカラ 一処方で比較したものである。明らかににモットリン グに関してはダブルコーティングに優位性があること が証明された訳である（図 3，4，5）。

\section{2 光沢発現性および平滑性}

笑験結果に亦す通り，闹一塗布量であってもダブル コーティングのオが高い光沢発現性, 平滑性が得られ ることが釷明された。また印刷光沢についても同様で ある。

\section{3 結 論}

3.1 久び 3.2 の結果から, ダブルコーティングを採

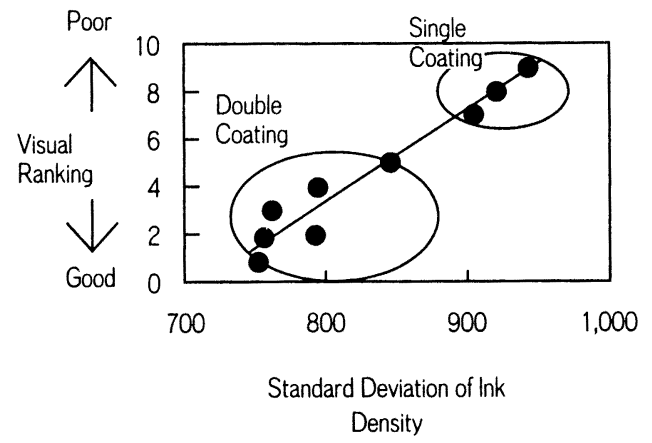

図 2 着肉濃度分散值と目視評価の関係

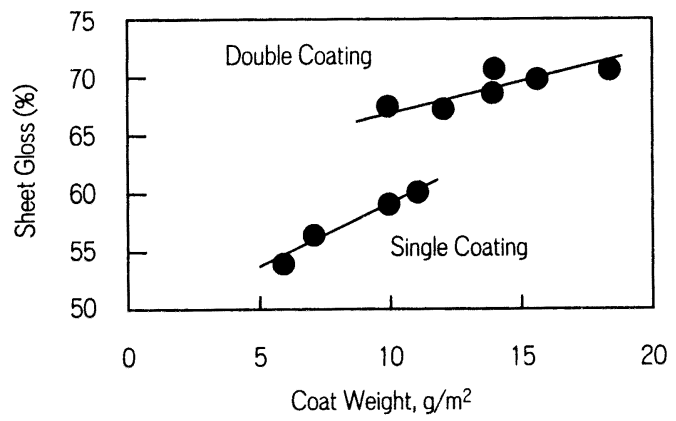

図 3 塗工量と白紙光沢度の関係

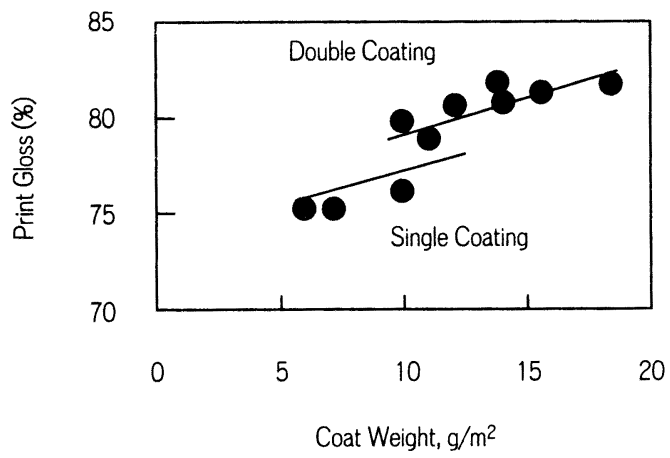

図 4 塗亡量と印面光沢度の関係

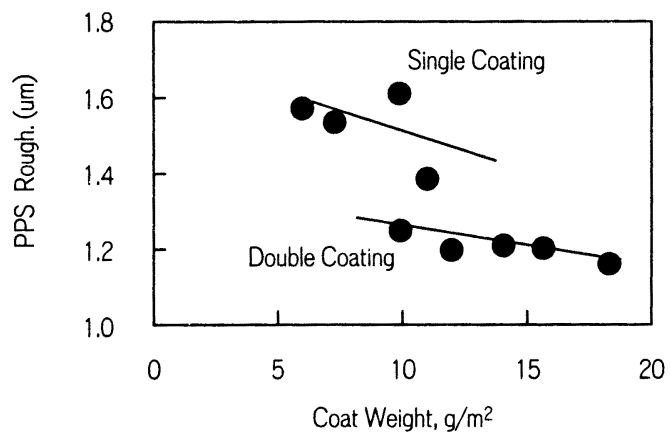

図 5 塗工量とPPSラフネスの関係 
用すればモットリングに対して, 乾燥条件やカラー処 うの許容範网が大きくなり，操業条件をあまり気にす る必要がなくなるという利点があると同時に, 同じ $\mathrm{A}_{2}$ グレードであれば，アンダーコートを安価な処力 にすることでコストダウンが四れること, 塗布量比率 を高为ることにより同一の原紙生産量で增産が可能に なること等々の利点を導くことができる。

基礎研究から得られたこれらの結論を元にダブルコ 一ト化改造が尖施された。

\section{4. 操 業 経 験}

\section{1 ストリーク対応}

\section{1 .1 ストリークの種類}

ストリークは巾が公くかなり彫り込ま机長く続く夕 イブ (1)， けが $0.5 \sim 1.0 \mathrm{~mm}$ 程度で比較的短く消減 するタイプ (2)), 巾が $0.5 \mathrm{~mm}$ 以下の椣めて細い夕 イプ (3)，大別するとこの 3 種類に分けられる。起 点と終末をサンプリングし，調査を行った結果をまと

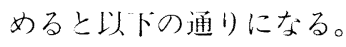

(1)のタイプは原紙表而の異物に由来する場合が多い。 とくに原料工程から持ち込まれるプラスティック類に は萝注意で, 抄紙機の精選【程で完全に除去すること はできない。発生源対策を要する。

(2)のタイプは原紙表面の原料，とくにある種の輸入 材を使ったときに顕著にその傾问が見受けられるべッ セル由来のものが多い。

(3)のタイブはカラー処方の影響で, ブレードでカラ 一を搔き落とす際に何等かの条件で発生するものであ る。ヒグメント配合, 高速流動性, 保水性, 原紙の昅 水性, ブレードの加尾条件等々がその因子になってい ると予想される。

こ机らの分類に漏れるストリークもあることはある が，その頻度は稀であり尃用の対策を要するのはこの 3 偅類といってよい。

\section{1 .2 ダブルコートにおけるストリーク対応}

(1)のタイプについて㷙述の通り発生源対策を行う必 要があるのはダブルコートに限ったことではない。

(2)のタイブについてはアンダーコートすることでそ の発生はほとんど皆無になるといえる。ダブルコート そのものがストリーク対策になっている。(3)のタプ がダブルコートの場合とくに注意しなければならない。

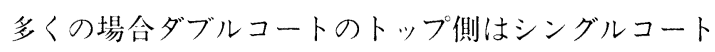
に比べ塗布量が少ないが, その際の処方, ブレード条 件, 濃度条件によって引き起こされる例が多い。セラ ミックブレードについては後述するが, これを使用し た場合その先端形状と材質に由来するであろうと推察
されるが(3のタイプのストリークが発生し易い傾问に あり, 注意を要する。我々は目標品質を維持しながら 高速流動性, 保水性を最適に保つためのカラー処方の 適正化とブレード条件の適正化によってこの開題を解 決した。

\section{2 プロファイルコントロール}

カッ夕後の製品の凸叫発生傾向は, ともすればダブ ルコートで発生しがちである。塗㬝が厚い!に泪 の塗にでシートがストレスを多く受けるため, スーパ カレンダの要因も加わって打音不圤を誘発するケース が多い。これを解消するためにはプロファイルの均一 化を网るだけでなく，全体のプロファイルをエッジお 向にトげる「夫と公配の見嫩めが重要になってくる。 マットコート紙で操業、要求されるプロファイルとは 対照的である（図 6,7,8）。

\section{3 乾燥}

モットリングの発生要素としてはシートの不均一性 と過度の乾燥によるバインダーマイグレーションが挙

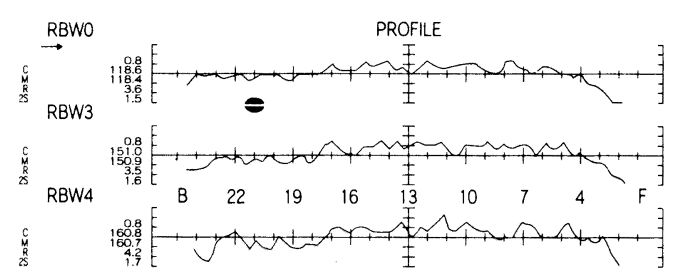

図 6 クロスマシン响プロファイル (グロス品)

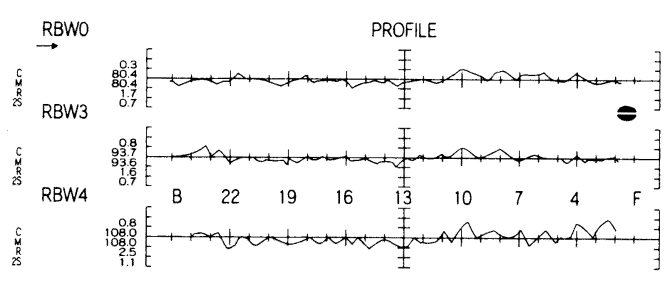

図 7 クロスマシン响のプロファイル (マット品)

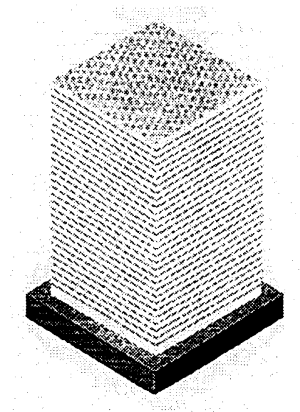

良好

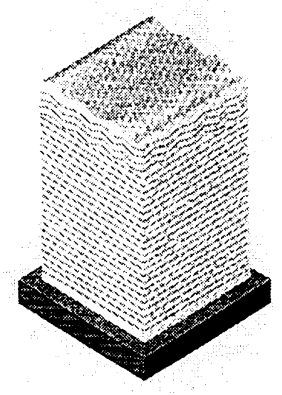

不良
図 8 断裁山 
げられる。ダブルコートの場合アンダーコートによっ てシート表面の均一性が増すと闹時に，塗工層一層の 厚みが小さくなり相对的に乾燥勾配が虐和されること になる。笑操業ではあまり乾燥条件に気を配らなくて も良い状沅となった。これらは推測の領域を出ないが, 実際の操業で結果として発現されている。

モットリングの印刷トラブルは皆無と言って良い状 沙が続いている。

\section{4 バッキングロール污れ}

ダブルコートの場合, トップコートの最終段でバッ キングロール沙れが発生し易い傾问がある。No.3 ッドの塗L層がNo.4 ヘッドのバッキングロールに接 触するが，この部分で塗「層表佰からラテックス成分 が転移し蓄積した結果バッキングロールが活れ，フロ ーリンドクタでト分に洗浄できない状況となり, 部分 的な水旧りトラブル, $\mathrm{CW}$ プロファイル不垦なよ゙を 引き起こす。愿罒は紙面温度の上昇, ラテックスの物 性などが考えられるが, メカニズムの解明には至って いない。我々はカラ一処方は:の対忍とラテックスの物 性改善によってこの䦌題を解決しな。

とくに，処方たの改着にせよ，ラテックスの物性に せよ，品筫要求を満起することが前提であり，ダブル コートで優位性のある特性については敬力操業性を改 善する才问で譲歩し，調製をおこなった。

\section{5 セラミックブレードの使用}

\#2 コータではセラミックブレードを採用している。 改善前からの取糺みでセラミックブレードを使いこな

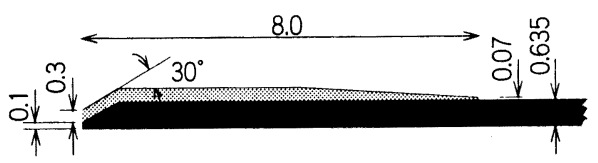

図 9 セラミックブレード外形闵
す操業面の技術を蓄積し，改造後は継続して使用して いる。特徵は(1)操作時の菠全性, (2)長寿命, (3) CW プロファイルの安定状態の継続性が挙げられる（図 9,

\section{表 1)。}

\subsection{1 操作時の安全性}

交換前のブレードであってもラウンドエリア部が残 つている状態であり，スチールブレードに比し刃先が 鋭利になっていないので, 取り外し取り付けの際の扱 いが容易である。

\section{5 .2 長 寿 命}

これまでの経過から，この生産ラインの原紙抄紙機 の速度とコータの速度には差が少なく余り余裕がもて ない状洗である。生産口スを最小限に食い止めるには コータでのロスタイムをいかに少なく止めるかが鍵に なっている。したがって，長寿命という特性は生産損 失を鼠小限に抑えるポイントになっている。現在では 抄紙機がフル連転してもコータが-十分追いつくところ まで落ち着いてきている。速度差は生産する坪量によ つても違いがあるが，ちなみに6 加の平均速度でみ ると抄紙機： $570 \mathrm{~m} / \mathrm{min}$,コー夕：600 m/minである。 またブレードの交換頻度が減少したことにより, 塗 り出し回数が減り損紙ロスが減少する效果も得られて いる。\#2コータの場合 4 へッドなのでこの利点は相 乗的に効果を発捙する結果となった。

\section{5 .3 安定状態の継続性}

归判主体の生産で打音交定は重要な課題であるが, 一おでダブルコーティングの弱点としてシングルの場 合より不笠定要素が增えるというジレンマがあった。 CWプロファイルの妾定状態の継続性によって，あ る程度プロファイルを落ち着かせればこれが継続的に 持続することによって，完璧とは棓えないまでも仕卜： 工程でのロスを許容範归内に收めることができた。

表 1 セラミックとスチールブレードの比較

\begin{tabular}{l|c|c|c}
\hline & $\begin{array}{c}\text { Calculation } \\
\text { Base }\end{array}$ & $\begin{array}{c}\text { Conventional } \\
\text { Steel Blade }\end{array}$ & $\begin{array}{c}\text { Coated } \\
\text { Blade }\end{array}$ \\
\hline Safety & - & Fair & Excellent \\
Blade Life & day & 1 & $3-4$ \\
Loss Time & $\mathrm{hr} /$ month & 1 & $1 / 4$ \\
Broke & $\mathrm{t} /$ month & 1 & $1 / 4$ \\
Loss Time by & $\$ /$ month & 1 & $1 / 4$ \\
Blade Change & $\$ /$ month & 1 & 3 \\
Blade Cost & $\$ /$ month & 1 & $4 / 5$ \\
\hline \multicolumn{1}{c}{ Tatal Loss } & & 1 & \\
\hline
\end{tabular}


表 2 生産性改善の例

\begin{tabular}{l|l|c|c|c}
\hline \multicolumn{2}{l|}{} & Single Coating & Double Coating & Difference \\
\hline Basis Weight & & & & - \\
Coated Paper & $\mathrm{g} / \mathrm{m}^{2}$ & 127.9 & 127.9 & $-10.0(-10 \%)$ \\
Base Paper & $\mathrm{g} / \mathrm{m}^{2}$ & 99.0 & 89.0 & $+10.0(+35 \%)$ \\
Coat Weight & $\mathrm{g} / \mathrm{m}^{2}$ & 28.9 & 38.9 & $+52.0(+21 \%)$ \\
\hline \multicolumn{1}{c}{ Production } & $\mathrm{t} /$ day & 253 & 305 & \\
\hline
\end{tabular}

\section{5 .4 そ $の$ 他}

これまではセラミックブレードの利点について述べ た訳であるが，難点もないわけではない。ストリーク 発生に対する感受性が高いこと, 制作精度による影響 が極めて敏感なことである。我々はこのセラミックブ レードを採用し、いくつかの失敗を糧に使いこなすま での各種の取組みを行うことにより，先に述べな優位 性を獲得するに至った。

\section{5. 成果と今後の展望}

\section{1 增 産}

表 2 に示した通り, $127.9 \mathrm{~g} / \mathrm{m}^{2}$ のコート紙の場合, 原紙坪量の減, 塗布量の増により抄紙機の增速分がそ のまま增産に繫がった。抄物構成その他の影響はある が, 全体の約 $10 \%, 800 \mathrm{t} / \mathrm{M}$ の增産が達成された (表 2)。

\section{2 コストダウン}

・カラー処方対応による比例費の削減

・七ラミックブレードの実現による損紙ロスの削減

\section{3 品質改善}

前述したように，モットリングその他の印刷適性が 大川の改善されたと同時に, 等月 7,000 台前後の平判 を生産する中で, 約 95\%はノ一選と呼んでいる無選 別台となった。後下程で発生する不良要因も含力, 月 当りの選別台は 350 台程度となり大巾な作業性改善が 達成された。

\section{4 将来展望}

我々が持っている設備の優位性を活かすためには, やはり高付加価值化が最も大きな将来への課題である。 このクラスの生産設備では, 收益性を十分勘案しなが よ将来への展望を作り上げなければならない。この考 え方に従い，年初よりアート紙の生産に取り組んでい る。既に数问の生産を実施し, 好評を得ているが, ア 一ト紙生産設借としてみれば政めて高い生産性在有し ている利点をいかし, 月に数下・切アト紙生産を達
成すべく企画を進めて行く考えである。

\section{参考文献}

1) Engström, G. Norrdahl, P. and Ström, G. : 1987 TAPPI Coating Conference Proceedings, 35 .

2) Arai, T., Sakai, K., Suzuki, T., Yamasaki, T. and Ogura, T. : 1988 TAPPI Coating Conference Proceedings, 187.

3) Kline, J.E. : 1988 TAPPI Coating Conference Proceedings, 29.

4) Fujiwara, H., Fujisaki, N., Shimizu, I. and Kano, I. : 1989 TAPPI Coating Conference Proceedings, 121.

5) Engström, G., Rigdahl, M., Kline, J.E. and Ahlroos, J. : 1991 TAPPI Coating Conference Proceedings, 169.

6) Fujiwara, H., Fujisaki, N. and Kaga, C. : 1991 TAPPI Coating Conference Proceedings, 179 .

7) Fujiwara, H., Kano, I. and Kaga, C. : 1990 TAPPI Coating Conference Proceedings, 209.

8) Macgregor, M.A. and Clemett, A. : 1990 TAPPI Coating Conference Proceedings, 125.

9) Shigetomi, K., Sakano, M., Fujihira, S. and Nagai, K. : 1991 TAPPI Coating Conference Proceedings, 483.

10) Lee, D.I. : 1988 TAPPI Coating Conference Proceedings, 103.

11) Fujiwara, H. and Kaga, C. : Tappi 75 (12) : 121-130 (1992).

12) Fujiwara, H., Wakai, C. and Kozuka, O. : 1993 Tappi Coating Conference Preprint: 9-16 (1993). 